\title{
LIGNOCELLULOLYTIC ENZYME PRODUCTION OF PLEUROTUS OSTREATUS GROWTH IN AGROINDUSTRIAL WASTES
}

\section{José Maria Rodrigues da Luz, Mateus Dias Nunes, Sirlaine Albino Paes, Denise Pereira Torres, Marliane de Cássia Soares da Silva, Maria Catarina Megumi Kasuya*}

Departamento de Microbiologia, Universidade Federal de Viçosa, Viçosa, MG, Brasil.

Submitted: January 18, 2011; Returned to authors for corrections: December 07, 2011; Approved: June 07, 2012.

\begin{abstract}
The mushroom Pleurotus ostreatus has nutritional and medicinal characteristics that depend on the growth substrate. In nature, this fungus grows on dead wood, but it can be artificially cultivated on agricultural wastes (coffee husks, eucalyptus sawdust, corncobs and sugar cane bagasse). The degradation of agricultural wastes involves some enzyme complexes made up of oxidative (laccase, manganese peroxidase and lignin peroxidase) and hydrolytic enzymes (cellulases, xylanases and tanases). Understanding how these enzymes work will help to improve the productivity of mushroom cultures and decrease the potential pollution that can be caused by inadequate discharge of the agroindustrial residues. The objective of this work was to assess the activity of the lignocellulolytic enzymes produced by two P. ostreatus strains (PLO 2 and PLO 6). These strains were used to inoculate samples of coffee husks, eucalyptus sawdust or eucalyptus bark add with or without $20 \%$ rice bran. Every five days after substrate inoculation, the enzyme activity and soluble protein concentration were evaluated. The maximum activity of oxidative enzymes was observed at day 10 after inoculation, and the activity of the hydrolytic enzymes increased during the entire period of the experiment. The results show that substrate composition and colonization time influenced the activity of the lignocellulolytic enzymes.
\end{abstract}

Key words: laccase, cellulase, mushrooms, lignocellulolytic residues.

\section{INTRODUCTION}

Edible mushroom cultivation can contribute to ecological recycling in addition to providing mushrooms that can be appreciated for their nutritional, medicinal and gastronomic characteristics $(2 ; 22)$. The mushroom market has grown continuously and technological advances have improved the quality and quantity of the mushrooms while reducing the costs of production (13). In Brazil, mushrooms production are a profitable crop (6), and they can be cultivated on different agricultural wastes, including coffee husks (29), corncobs (14), sawdust (7), eucalyptus bark (5) and sugar cane bagasse (21). The use of these residues depends on the capacity of the fungus to produce a lignocellulolytic enzyme complex (4). This complex includes the oxidative enzymes laccase and manganese peroxidase (MnP), which are involved in lignin degradation $(8 ; 10 ; 27)$, and the hydrolytic enzymes xylanase and cellulase (6), which are involved in hemicellulose and 
cellulose degradation, respectively. The fungi that produce this enzymatic complex are known as white rot fungi, and the genus Pleurotus is unique among them (2). This fungus is able to grow well on residues with a high carbon/nitrogen ratio (6, 30 ) and at a temperature between 25 and $30{ }^{\circ} \mathrm{C}$ (6). Additionally, it is easy to handle and exhibits highly productive growth on cheap and abundant substrates (26).

However, the composition of the substrate affects the productivity and chemical composition of the mushrooms (28); therefore, it is important to choose adequate substrates. For production of Pleurotus on agricultural wastes, the supplementation with rice bran has been suggested (6). The objectives of this work were 1) to assess the lignocellulolytic enzyme activity of two strains of $P$. ostreatus cultivated on different agroindustrial wastes and 2) to evaluate the ability of rice bran supplementation to increase mushroom production.

\section{MATERIALS AND METHODS}

\section{Strains and inoculum preparation}

Strains PLO 2 and PLO 6 of Pleurotus ostreatus, obtained from the laboratory Association Mycorrhizal / Department of Microbiology/ Bioagro/ Federal University Viçosa, were cultivated on BDA (Barley Dextrose Agar) medium, $\mathrm{pH}$ 5.8, and incubated for $15 \mathrm{~d}$ at $25{ }^{\circ} \mathrm{C}$. The spawn was prepared in glass pots using pre-cooked and autoclaved rice grains and was inoculated with four 1-cm-diameter agar disks containing mycelia. The cultures were then incubated at $25^{\circ} \mathrm{C}$ for $20 \mathrm{~d}$.

\section{Substrate preparation and inoculation}

The agroindustrial wastes tested were coffee husks, eucalyptus sawdust and eucalyptus bark, with or without $20 \%$ rice bran. Coffee husks (Ca) were washed with water to remove impurities, boiled for $2 \mathrm{~h}$ and centrifuged for $5 \mathrm{~min}$ using a home centrifuge (Mueller, Nina Soft). Eucalyptus sawdust (Se) was passed through a 2-mm sieve. Five hundred grams of each substrate was packed in a polypropylene bag and sterilized twice for two hours at $121{ }^{\circ} \mathrm{C}$ with $48 \mathrm{~h}$ between sterilizations. The substrates were inoculated by adding $75 \mathrm{~g}$ of spawn to each bag, after which all bags were incubated at $25^{\circ} \mathrm{C}$.

\section{Sampling and enzymatic activities}

Samples were taken at days 5, 10 and 15 after inoculation. Samples were taken from three different random points of the colonized substrate.

Mushroom production: After the appearance of fruiting bodies, the polyethylene bags were transferred to a fructification room with about $90 \%$ humidity and a temperature about $20{ }^{\circ} \mathrm{C}$. The mushrooms were harvested after 18 to 20 days, weighed and stored in a refrigerator. The biological efficiency (BE) was calculated as the ratio between the mass of fresh mushroom and the dry mass of the substrate, multiplied by 100 .

Crude enzymatic extract: Samples of $20 \mathrm{~g}$ of substrate were placed in an Erlenmeyer flask $(250 \mathrm{~mL})$ with $100 \mathrm{~mL}$ sodium citrate buffer $(50 \mathrm{mM}, \mathrm{pH} 4.8)$ and were agitated at 150 rpm for $1 \mathrm{~h}$. The crude enzymatic extract (EEB) was the filtrate obtained after separation of the residues using filter paper (Whatman n. 1). The EEBs were stored in a refrigerator until use. Enzymatic assays were done in triplicate, and a zero reaction was performed using the substrates before fungus inoculation.

Enzymatic Activity: The MnP activity was determined as described by Kuwahara et al. (15) using a solution of phenol red $\left(1 \mathrm{~g} \mathrm{~L}^{-1}\right)$ as substrate. For the reaction we used $100 \mu \mathrm{L}$ phenol red, $200 \mu \mathrm{L}$ sodium lactate, $300 \mu \mathrm{L}$ BSA $(0.5 \%), 50$ $\mu \mathrm{L}$ manganese sulfate II, $100 \mu \mathrm{L}$ hydrogen peroxide in sodium succinate buffer ( $2 \mathrm{M}, \mathrm{pH} 4.5), 100 \mu \mathrm{L}$ fungal extract and 150 $\mu \mathrm{L}$ distilled water. The reaction was incubated at $37^{\circ} \mathrm{C}$ for 15 minutes. The reaction was stopped with $40 \mu \mathrm{L}$ of sodium hydroxide (2M). The absorbance was measured at $610 \mathrm{~nm}$.

The laccase activity was determined as described by Buswell et al. (4) using 2,2'-azinobis-3-ethylbenzthiazoline-6-sulfonate (ABTS) as substrate. For the reaction we used $300 \mu \mathrm{L}$ of sodium acetate buffer (0.1 M, pH 5.0), $200 \mu \mathrm{L}$ of ABTS (1 $\mathrm{mM}$ ) dissolved in distilled water $100 \mu \mathrm{L}$ fungal extract and 
$400 \mu \mathrm{L}$ distilled water. The reaction was incubated at $37^{\circ} \mathrm{C}$ for $15 \mathrm{~min}$. The oxidation of ABTS was measured by the increase in absorbance with $420 \mathrm{~nm}$ at $37^{\circ} \mathrm{C}$ for $1 \mathrm{~min}$.

The activity of cellulase (18) and xylanase (1) were determined by measuring the amount of sugar reduced using DNS (3,5-dinitrosalicylic acid) methodology.

Reduced sugar: The amount of reduced sugar present in the samples was determined using DNS methodology, and standard curves for glucose and xylose were constructed using concentrations between 0.5 and $1.5 \mathrm{~g} \mathrm{~L}^{-1}$. The absorbance at $540 \mathrm{~nm}$ was measured using a spectrophotometer.

Soluble protein: The soluble protein concentrations were evaluated using a colorimetric method based on the standard curve of bovine serum albumin at $595 \mathrm{~nm}$ (3).

Statistical analyses: The experiments were conducted using a completely randomized design consisting of a $6 \times 2 \times 3$ factorial design, with six substrates, two fungi strains and three periods of mycelial growth on the substrate. Analysis of variance and Tukey test using a $5 \%$ level of significance were used to compare the results for the different media using software Saeg (version 9.1 - Federal University Viçosa, 2007).

\section{RESULTS}

The fungi strains formed primordia $15 \mathrm{~d}$ after inoculation. There was difference in the BE between strains PLO 2 and PLO $6(\mathrm{P}>0.05)$ and substrates add with $20 \%$ rice bran, the colonization was more uniform (data not shown) and had a higher BE (Figure 1).

Manganese peroxidase activity $(\mathrm{MnP})$ was highest on $10^{\text {th }}$ day for the eucalypt sawdust with $20 \%$ rice bran $(\mathrm{SeFa})$ and coffee husks with $20 \%$ rice bran (CaFa). (Figures $2 \mathrm{~A}$ and $2 \mathrm{~B}$ ). Additionally, independent of substrate, the strain PLO 6 had higher activity of $\mathrm{MnP}$.

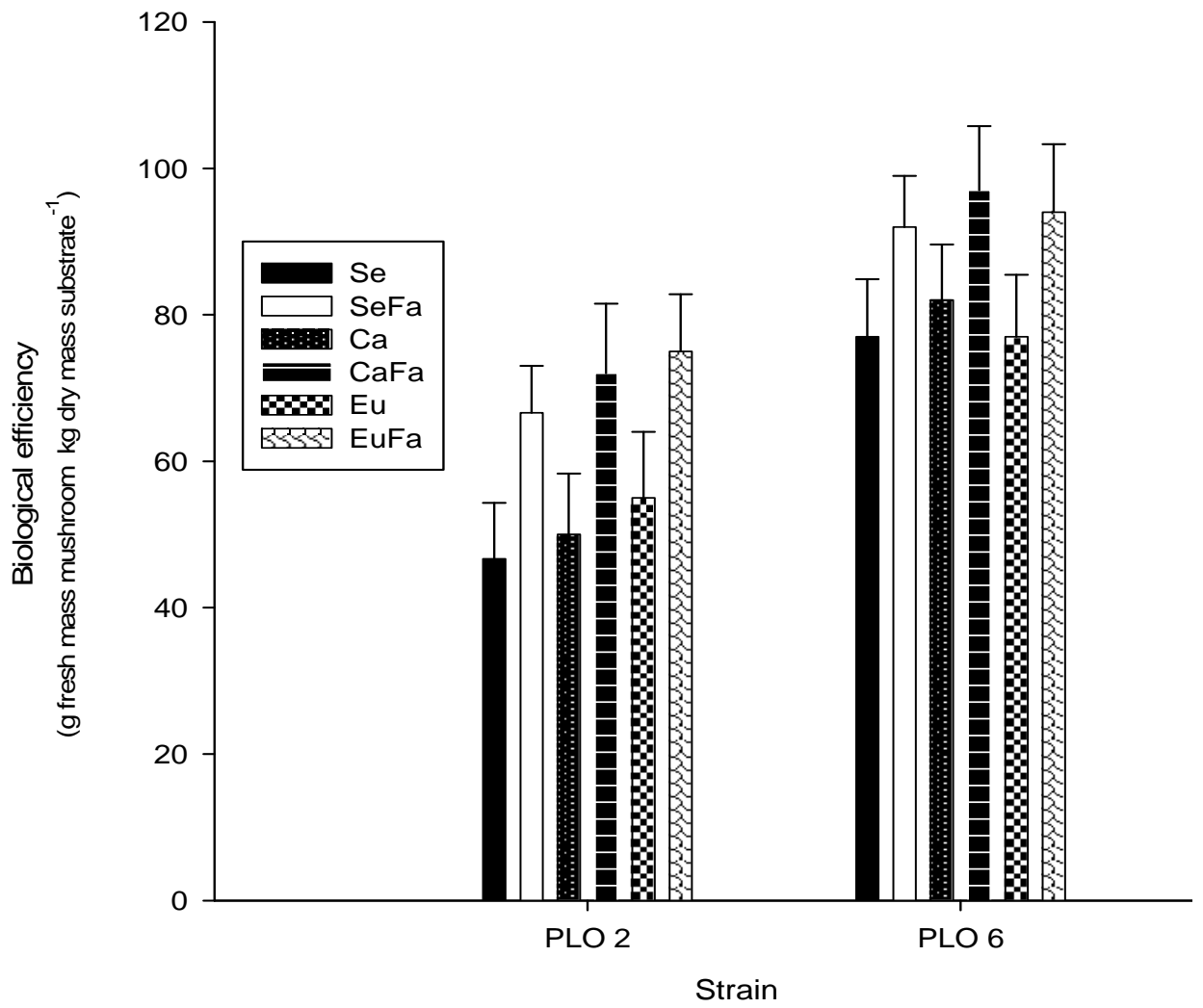

Figure 1. Mushroom biological efficiency of Pleurotus ostreatus growth in substrate based on sawdust (Se), sawdust with $20 \%$ rice bran $(\mathrm{SeFa})$, coffee husk $(\mathrm{Ca})$, coffee husk with $20 \%$ rice bran $(\mathrm{CaFa})$, eucalypt bark $(\mathrm{Eu})$ and eucalypt bark with $20 \%$ rice bran (EuFa) with day 15 of incubations at $25^{\circ} \mathrm{C}$. 
The laccase activity was greater than the $\mathrm{MnP}$ activity (Figures 2 and 3), and no difference was observed between the strains $(\mathrm{P}>0.05)$. The highest activity was observed on $\mathrm{CaFa}$ and SeFa (Figure 3A and 3B).

The enzyme activity responsible for cellulose and hemicellulose degradation increased with the incubation time and increased also during the formation of fruiting bodies for both strains (Figures 4 and 5). The cellulase and xylanase activity were higher for strain PLO 6 and for substrates add with rice bran. (Figures 4A-B and 5A-B).

Soluble protein increased during the colonization time, mainly in substrates with added rice bran (Figures 6A and 6B).
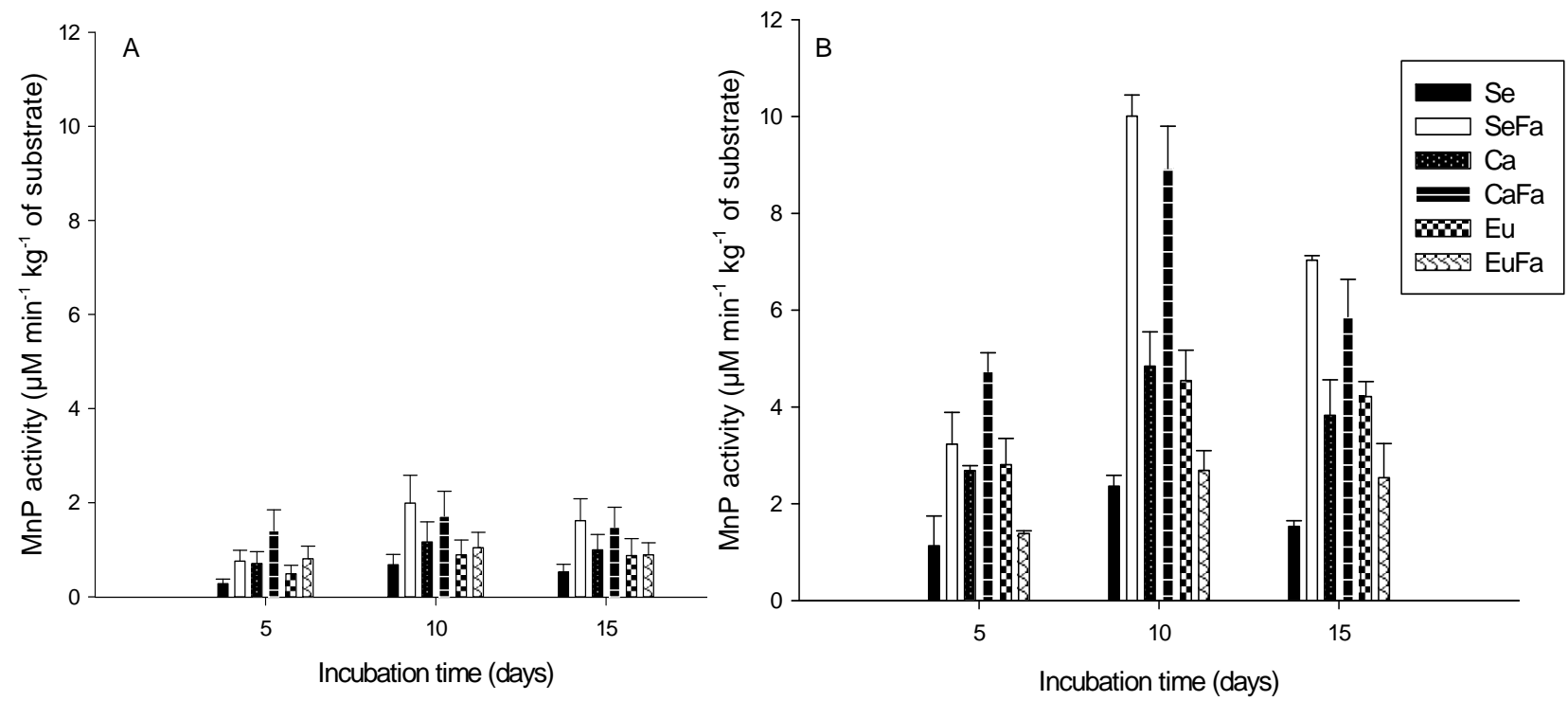

Figure 2. Manganese activity peroxidase (MnP) of Pleurotus ostreatus, strains PLO 2 (A) and PLO 6 (B), growth in substrate based on sawdust (Se), sawdust with $20 \%$ rice bran $(\mathrm{SeFa})$, coffee husk $(\mathrm{Ca})$, coffee husk with $20 \%$ rice bran $(\mathrm{CaFa})$, eucalypt bark (Eu) and eucalypt bark with $20 \%$ rice bran (EuFa), at days 5,10 and 15 after incubations at $25{ }^{\circ} \mathrm{C}$.
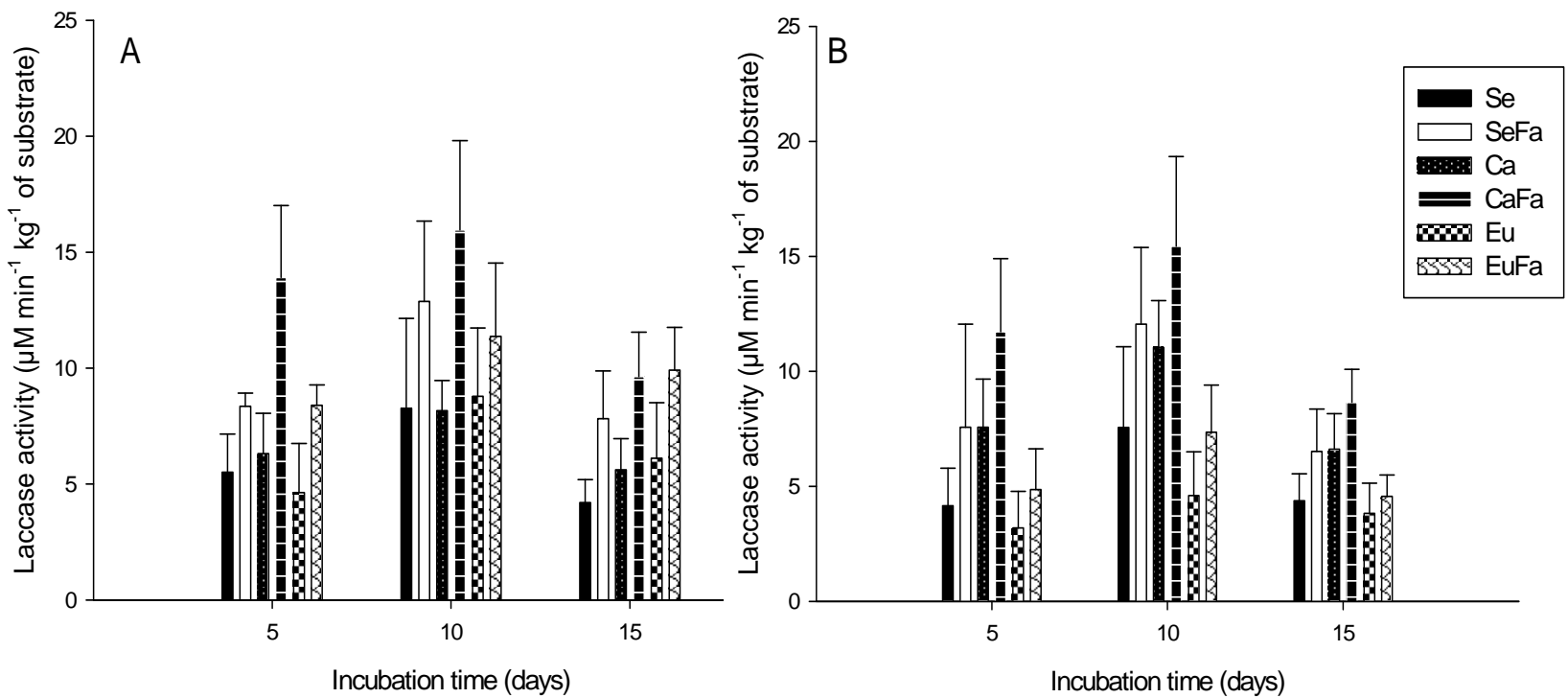

Figure 3. Laccase activity of Pleurotus ostreatus, strains PLO 2 (A) and PLO 6 (B), growth in substrate based on sawdust (Se), sawdust with $20 \%$ rice bran $(\mathrm{SeFa})$, coffee husk $(\mathrm{Ca})$, coffee husk with $20 \%$ rice bran $(\mathrm{CaFa})$, eucalypt bark $(\mathrm{Eu})$ and eucalypt bark with $20 \%$ rice bran (EuFa), at days 5,10 and 15 after incubations at $25^{\circ} \mathrm{C}$. ${ }^{*}$ There was no difference between strains PLO 2 and PLO 6 (P>0 0 05) 

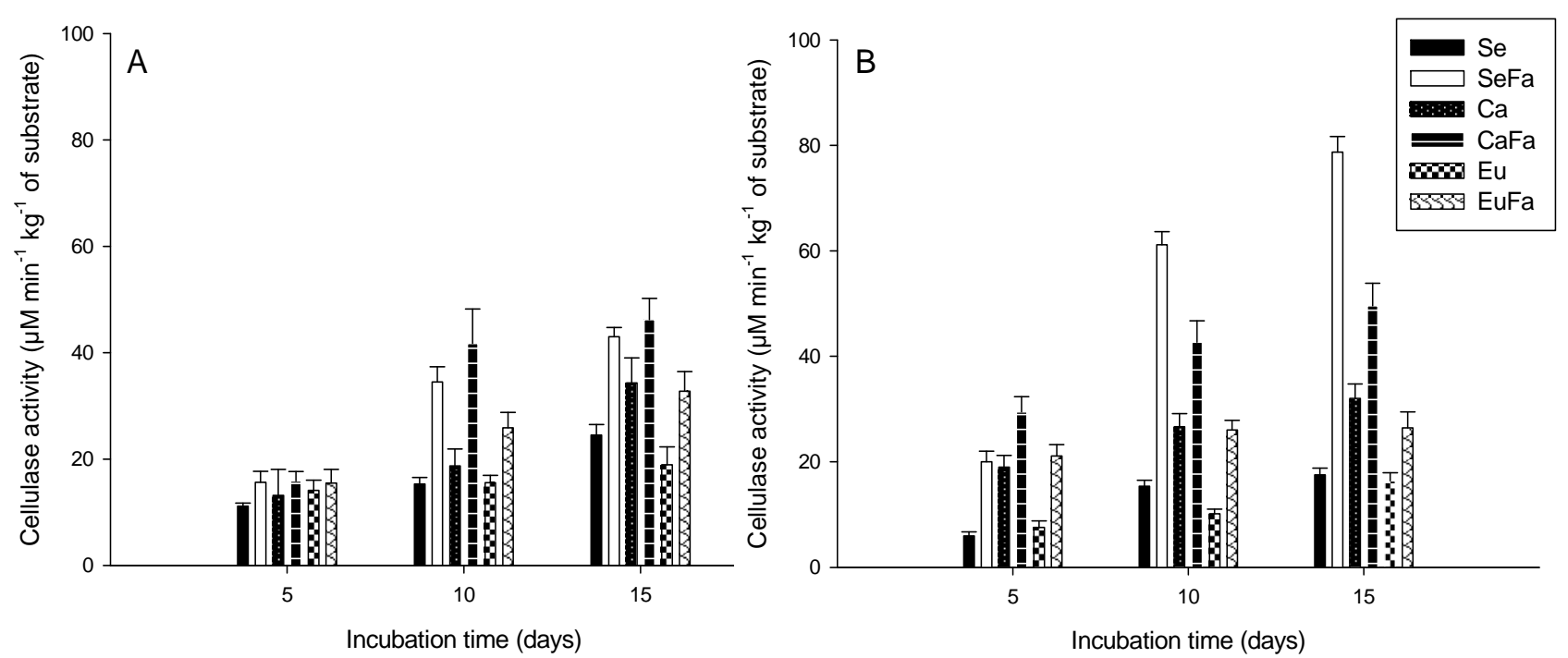

Figure 4. Cellulase activity of Pleurotus ostreatus, strains PLO 2 (A) and PLO 6 (B), growth in substrate based on sawdust (Se), sawdust with $20 \%$ rice bran (SeFa), coffee husk $(\mathrm{Ca})$, coffee husk with $20 \%$ rice bran $(\mathrm{CaFa})$, eucalypt bark (Eu) and eucalypt bark with $20 \%$ rice bran (EuFa), after 5, 10 and 15 days incubations at $25^{\circ} \mathrm{C}$.
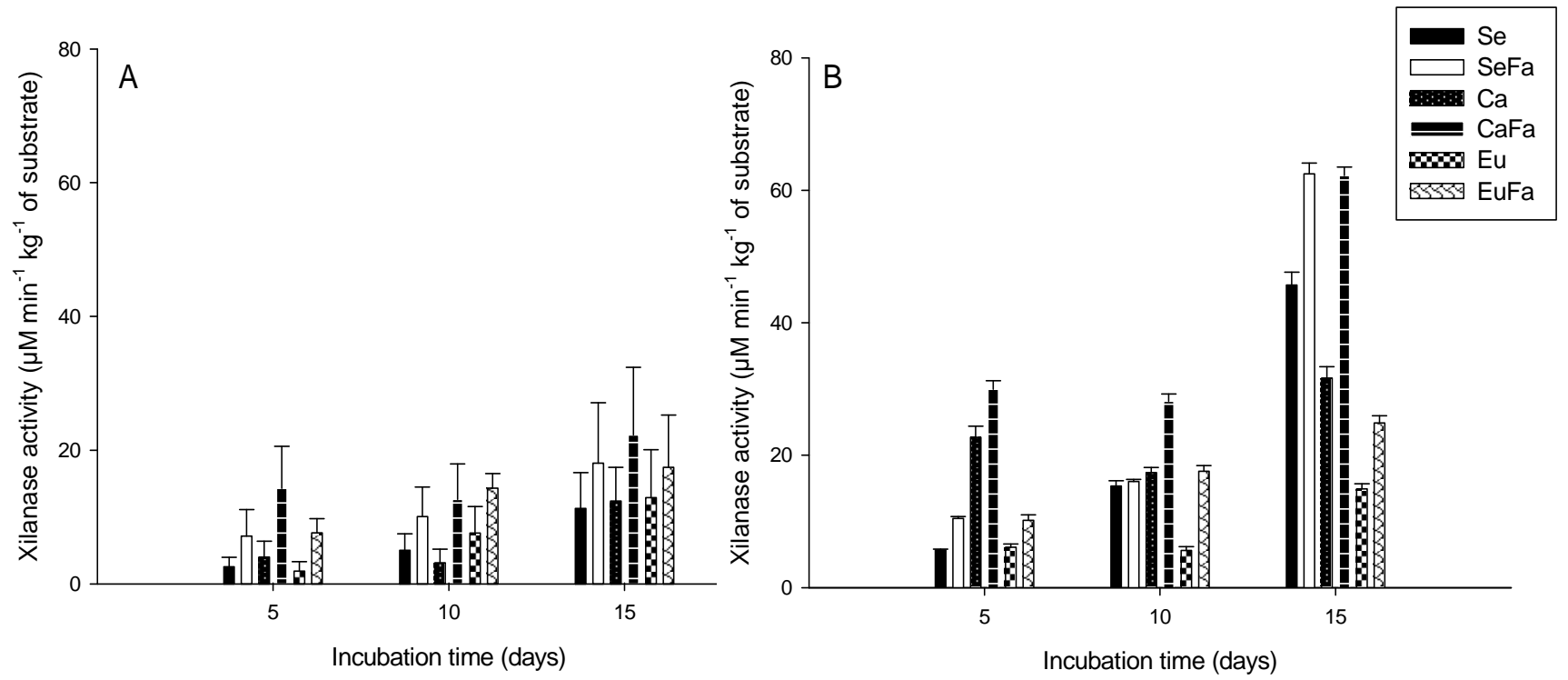

Figure 5. Xylanase activity of Pleurotus ostreatus, strains PLO 2 (A) and PLO 6 (B), growth in substrate based on sawdust (Se), sawdust with $20 \%$ rice bran (SeFa), coffee husk (Ca), coffee husk with $20 \%$ rice bran $(\mathrm{CaFa})$, eucalypt bark (Eu) and eucalypt bark with $20 \%$ rice bran (EuFa), at days 5,10 and 15 after incubations at $25^{\circ} \mathrm{C}$. 

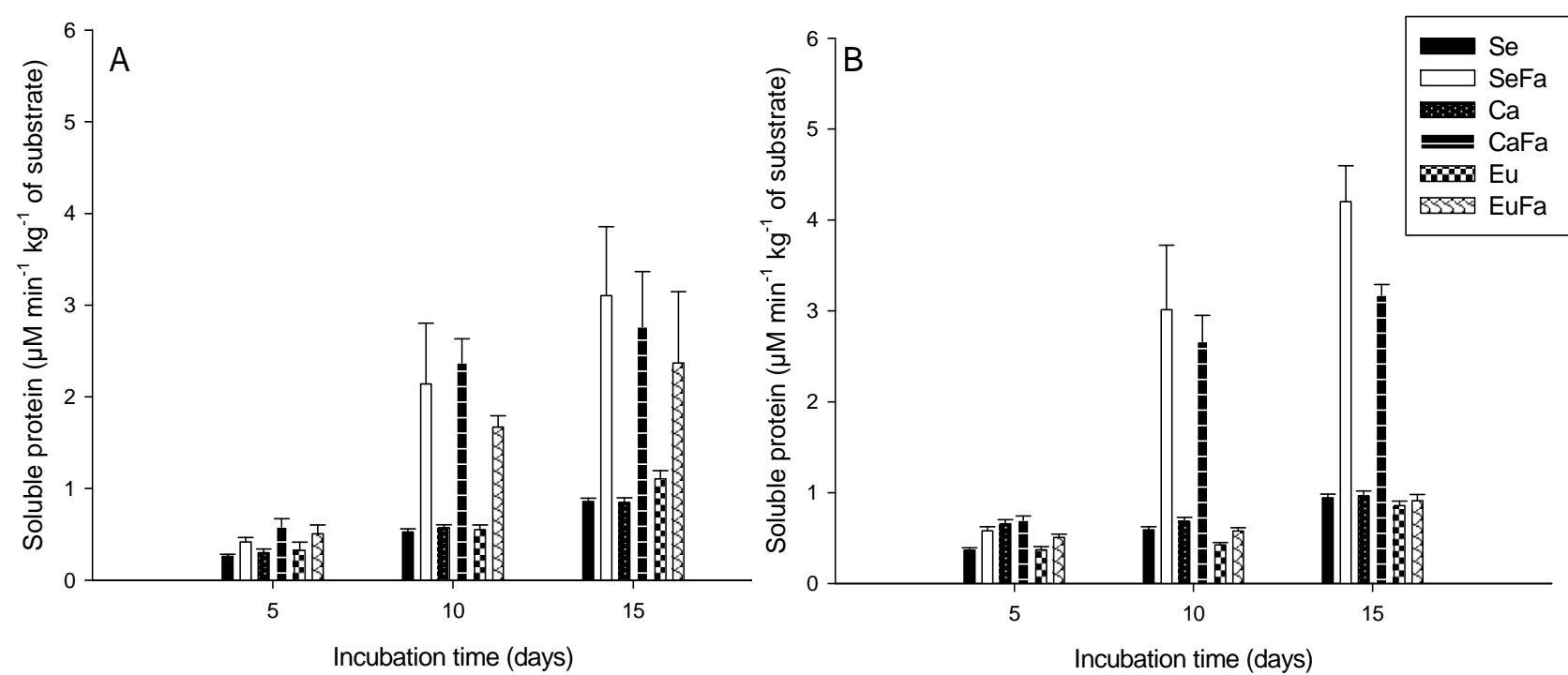

Figure 6. Soluble protein concentration of Pleurotus ostreatus, strains PLO 2 (A) and PLO 6 (B), growth in substrate based on sawdust (Se), sawdust with $20 \%$ rice bran ( $\mathrm{SeFa}$ ), coffee husk (Ca), coffee husk with $20 \%$ rice bran (CaFa), eucalypt bark (Eu) and eucalypt bark with $20 \%$ rice bran (EuFa), at days 5,10 and 15 after incubations at $25^{\circ} \mathrm{C}$.

\section{DISCUSSION}

This results show that $P$. ostreatus has great potential to transform agroindustrial wastes into products with high economic value, such as mushrooms and enzymes, in addition to contributing to environmental protection by preventing inadequate discharge or the incineration of these wastes.

The increase in the biological efficiency for substrates supplemented with rice bran (Figure 1) was verified when Pleurotus and $L$. edodes were cultivated on different agricultural wastes, such as eucalyptus sawdust and bark, corncobs, coffee husks and sugar cane (25). These results demonstrate the importance of adding a nitrogen source to reduce the $\mathrm{C} / \mathrm{N}$ ratio of the lignocellulosic residues for mushroom cultivation.

Lignocellulolytic enzyme activity in substrates with or without rice bran (Figures 2, 3, 4, 5) has been measured for other fungi species $(5 ; 9 ; 16 ; 24)$. The results of these studies demonstrate the importance of lignocellulolytic enzymes for the utilization of lignin, cellulose and hemicellulose as carbon sources.
Hydrolytic enzyme activity increased during incubation time (Figures 4, 5) with the highest activity during primordial formation, have also been reported by Matsumoto (20) for $L$. edodes cultivated on eucalyptus sawdust. Matsumoto found that the cellulase and xylanase activities increased during the development of the fruiting bodies, with highest levels during mushroom maturation. The increase in the enzyme activities during fructification may be due to the fungus's need to mobilize large amounts of carbon for mushroom formation (19).

The higher enzyme activities observed for strain PLO 6 relative to PLO 2 (Figures 2, 4 and 5) could be the result of genetic variability, as demonstrated Ribeiro (25), who found genetic differences between these isolates using RAPD (Rapid Amplification of Polymorphic DNA). These genetic differences could influence both the differential expression of lignocellulolytic enzymes and the production of fruiting bodies. The difference in enzyme activity between the strains could also be attributed to the culture conditions because the experiments were conducted during different climatic periods, showing the importance of selecting the appropriate strain for 
each period of the year and for each climatic region.

The higher activity of the lignocellulolytic enzymes observed when the substrates were supplied with rice bran (Figures 2, 3, 4 and 5) has also been observed for L. edodes and Phanerochaete chrysosporium (16). This higher activity could be the result of an increase in the availability of monosaccharides, polysaccharides or nitrogen $(16,17)$. The production of cellulase by Polyporus grown on palm waste increased when the amount of cassava in the substrate decreased (11), probably because this reduced the $\mathrm{C} / \mathrm{N}$ ratio. The addition of rice bran to cassava bagasse also increased the activity of xylanase produced by Thermoascus aurantiacus (23). Supplementation of nitrogen in rice straw increased the production of laccase 3-4 times in lignocellulolytic fungus (9). The lignocellulolytic enzyme activity is dependent on the composition of the substrate and on the $\mathrm{C} / \mathrm{N}$ ratio, as reported by Kahraman and Gurdal (12). According to these authors, factors affecting the activity and production of these enzymes include the availability of oxygen, the carbon and nitrogen concentrations, the $\mathrm{pH}$ and the temperature.

Our results show that it is important to select mushroom isolates based on the culture conditions because there are isolate-specific variations in mushroom production (Figure 1) and in the activities of lignocellulolytic enzymes under different conditions (Figure 2, 3, 4 and 5). Moreover, the addition of rice bran to lignocellulosic substrates increased the production of soluble proteins, the enzyme activity and the productivity of white rot fungi, confirming the importance of supplementation with an $\mathrm{N}$ source like rice bran.

\section{CONCLUSION}

Strains PLO 2 and PLO 6 of P. ostreatus form fruiting bodies on coffee husks, sawdust and eucalyptus bark with or without the addition of rice bran, emphasizing highest hydrolytic enzyme activity during the formation of these fruiting bodies. The highest oxidative enzyme activity was observed on day 10 after inoculation. Thus, addition of $20 \%$ rice bran stimulated the activity of lignocellulolytic enzymes and increased the biological efficiency.

\section{ACKNOWLEDGEMENTS}

The authors gratefully acknowledge the National Counsel of Technological and Scientific Development (CNPq) and Research Support Foundation of Minas Gerais (FAPEMIG).

\section{REFERENCES}

1. Bailey, M..J.; Biely, P.; Pantonen, K., 1992. Interlaboratory testing of methods for assay of xylanase activity. J. Biotech., 23, 257-270.

2. Bonatti, M.; Karnopp, P.; Soares, H. M.; Furlan, S. A., 2004. Evaluation of Pleurotus ostreatus and Pleurotus sajor-caju nutritional characteristics when cultivated in different lignocellulosic wastes. Food Chem., 88, 425-428.

3. Bradford, M.M., 1976. A rapid and sensitive method for the quantitation of microgram quantities of protein utilizing the principle of protein dye binding. Anal. Biochem., 72, 248-254.

4. Buswell, J.; Cai, Y. J.; Chang, S.T., 1995. Effect of nutrient nitrogen and manganese or manganese peroxidase and laccase production by Lentinula (Lentinus) edodes. FEMS Microbiol Lett., 128, 81-88.

5. Cavallazzi, J. R. P.; Brito, M. S.; Oliveira, M.G.A.; Bôas, S.G. V.; Kasuya, M.C.M., 2004. Lignocellulolytic enzymes profile of three Lentinula edodes (Berk.) Pegler strains during cultivation on eucalyptus bark-based medium. J Food Agr. Environ., 2, 291-297.

6. $\quad$ Eira, A.F., 2004. Fungos comestíveis. In: Esposito, e Azevedo, J. L. (ed.) Fungos: uma introdução à biologia, bioquímica e biotecnologia. Editora UCS, Caxias do Sul, Brazil, p.15-46.

7. Fasidi, I. 0., 1996. Studies on Volvariella esculenta (Mass) Singer: cultivation on agricultural wastes and proximate composition of stored mushrooms. Food Chem., 55 (2), 161-163.

8. Galliano, H.; Gas, G.; Seris, J.L.; Boudet, A.M. (1991). Lignin degradation by Rigidoporus lignosus involves synergistic action of two oxidizing enzymes: Mn peroxidase and laccase. Enzyme Microb. Tech., $13,478-482$.

9. Gomes, E., Aguiar, A.P., Carvalho, C.C., Bonfá, M.R.B., Silva, R., Boscolo, M., 2009. Ligninases production by Basidiomycetes strains on lignocellulosic agricultural residues and their application in the decolorization of synthetic dyes. Braz. J. Microbiol., 40:1, 31-39.

10. Hofrichter M., 2002. Review: lignin conversion by manganese peroxidase (MnP). Enzyme Microb. Tech., 30, 454-466.

11. Israel, C.M., 2005. Utilização do Resíduo do Processamento do Palmiteiro para a Produção de Enzimas Hidrolíticas por Fungos do Gênero Polyporus. Blumenau, Brazil, 100 p. (M.Sc. Dissertation, Engenharia Ambiental do Centro de Ciências Tecnológicas). 
12. Kahraman, S.S.; Gurdal, I.H. (2002). Effect of synthetic and natural culture media on laccase production by white rot fungi. Bioresour. Technol., 82, 215-217.

13. Kasuya, M.C.M.; Vanetti, M.C.D; Manabe, A.; Santana, C.C.;Mendonça, M. (2004). Shiitake log cultivation in Brazil. In: Shiitake Cultivation. Mush World, pp. 74-80.

14. Kihumbu, A. G.; Anakalo, S. A.; Maina, M. S.; Khare, K.B. Sharma, H. K. (2008). Nutritional Composition of Pleurotus sajor-caju Grown on Water Hyacinth, Wheat Straw and Corncob Substrates. Res. J. Agric. Biol. Sci. 4, 321-326.

15. Kuwahara, M.; Glenn, J.K.; Morgan, M.A. (1984). Separation and characterization of two extracellular $\mathrm{H}_{2} \mathrm{O}_{2}$-dependent oxidases from ligninolytic cultures of Phanerochaete chrysosporium. FEMS Microbiol. Lett., 169, 247-250.

16. Leatham, G.F.; Kirk, T.K. (1983). Regulation of ligninolytic activity by nutrient nitrogen in white-rot basidiomycetes. FEMS Microbiol. Lett., 16, 65-67.

17. Leatham, G.F. (1985). Extracellular enzymes produced by the cultivated mushroom Lentinus edodes during degradation of a lignocel-lulosic medium. Appl. Environ Microbiol., 50, 859-867.

18. Mandels, M.; Andreotti, R.; Roche, C., 1976. Measurement of saccharifying cellulase. Biotechnol. Bioeng., 6, 21-33.

19. Mata, G.; Savoie, J.M., (1998). Extracellular enzyme activities in six Lentinula edodes strains during cultivation in wheat straw. World $J$. Microbiol, 14, 513-519.

20. Matsumoto, T., (1998). Changes in activities of carbohydrases, phosporylase, proteinases and phenol oxidases during fruiting of Lentinula edodes in sawdust cultures. Tottori Mycol. Inst., 26, 46-54.

21. Moda, E. M.; Horii, J.; Spoto, M. H. F., (2005). Edible mushroom
Pleurotus sajor-caju production on washed and supplemented sugarcane bagasse. Sci Agric., 62, 127-132.

22. Moradali, M. F.; Mostafavi, H.; Ghods, S.; Hedjaroude, G. A. (2007). Immunomodulating and anticancer agents in the realm of macromycetes fungi (macrofungi). Inst. Immunopharmacol., 7, 701-724.

23. Palma, M.B., (2003). Produção de xilanases por Thermoascus aurantiacus em cultivo em estado sólido. Florianópolis, Brazil, 96 p. (D. Sc., Universidade Federal de Santa Catarina. UFSC).

24. Pickard, T.; Duhalt, V. (2001). Kinetic differences of purified laccases from six Pleurotus ostreatus strains. Lett. Appl. Microbiol., 32, 331.

25. Ribeiro, J.J.O., (2009). Produção e caracterização de cogumelos comestíveis cultivados em resíduos agroindustriais. Viçosa, Brazil, 120 p. (D. Sc. Universidade Federal de Viçosa. UFV).

26. Schmidt, P.; Wechsler, F. S.; Nascimento J.S.; Vargas, F. M. J. (2003). Tratamento do feno de braquiária pelo fungo Pleurotus ostreatus. $R$. Bras. de Zootec., 32, 1866-1871.

27. Shah, V.; Nerud F. (2002). Lignin degrading system of white-rot fungi and its exploitation for dye decolorization. Can. J. Microbiol., 48, 857870 .

28. Shashirekha, M.N.; Rajarathnam, S.; Bano, Z. (2005). Effects of supplementing rice straw growth substrate with cotton seed on the analytical characteristics of the mushroom, Pleurotus florida (Block \& Tsao). Food Chem., 92, 255-259.

29. Silva, M.C.S.; Naozuka, J.; Oliveira, P.V.; Vanetti, M.C.D.; Bazzolli, D.M.S.; Costa, N.M.B.; Kasuya, M.C.M., 2010. In vivo bioavailability of selenium in enriched Pleurotus ostreatus mushrooms. Metallomics, 2, $162-166$.

30. Zhang, C.K.; Gong, F.; Li, D.S., 1995. A note on the utilization of spent mushroom compost in animal feed. Bioresour. Technol., 52, 89-91. 